\title{
Sophus Schack og slaget ved Ullerup 1849
}

\section{Af Sigvard Skov.}

Til treårskrigens illustrering foreligger et rigt og omfattende billedmateriale, der spænder fra tarvelige skillingstryk til monumentale bataillemalerier. Nogle er rene fantasiprodukter, mens andre mere eller mindre direkte knytter sig til syns- og oplevelsesindtryk fra slagmarken. Ved krigens udbrud meldte adskillige unge malere sig som frivillige til hærens rækker. De medførte skitsebog og blyant i tornystret, og så snart der var en ledig stund, fik de tegnerekvisitterne frem og fæstnede i raske rids feltlivets hændelser til papiret. Som aktive soldater havde de naturligvis kun sjældent lejlighed til at tegne, mens kampen stod på. Det havde derimod flere ældre kunstnere, der havde fảet tilladelse til at følge hæren for at gøre skitser på stedet til brug for de store slagbilleder, som de senere komponerede hjemme i atelieret. Alle kendte samtidige billeder, såvel grafiske som tegnede og malede, har Jørgen Paulsen samlet, registreret og kommenteret på forbilledlig vis i sin store af Frederiksborgmuseet udgivne bog fra 1952. ${ }^{1}$ Fuldstændighed er naturligvis uopnåelig $i$ værker af den slags, og det er et rent tilfælde, at et hidtil ukendt slagbillede af S. P. L. Schack her kan fremlægges.

Mens flere af de førnævnte unge kunstnere, der meldte sig frivilligt, efterhånden avancerede og grebet af militærlivet også efter krigens ophør forblev i hærens rækker, var Sophus Peter Larsenius Schack (1812-64) faktisk gået den modsatte vej. Han var søn af generalfiskal og kammeradvokat Gregers Schack og indtrådte 9 år gammel i landkadetkorpset. Ved den nye hærordnings gennemførelse i 1842 var han avanceret til premierløjtnant, men valgte da at forlade militærlivet for at dyrke kunsten.

Fra 1835 eller 36 var Schack elev af Kunstakademiet. Samtidig malede han i Eckersbergs malerstue. I 1837 rykkede han op i modelskolen, vandt samme år den lille og året efter den store solvmedaille. Efter at have forladt hæren drog han i 1844 ud på 
den for datidens kunstnere uomgængelige studierejse, og Schack besøgte både Paris og Italien. Allerede i 1836 havde Schack som akademielev udstillet på Charlottenborg, og han vedblev dermed til sin død i 1864. I Schacks produktion findes et antal respektable portrætter, f. eks. af Thorvaldsen og J. L. Heiberg, samt et par altertavler. Kongeskiftet i 1839 medførte, at Schack forst kom til at male Frederik VI pá lit de parade, ${ }^{2}$ billedet udstilledes på Charlottenborg 1840, og derefter den nye konge, Christian VIII's kroning i Frederiksborg slotskirke. Dette billede er hans mest kendte og vel ogsâ hans betydeligste værk. Det er interessant ved sit motiv, den sidste kongekroning i Danmark, altså et billede fra samtidshistorien med en sammentrængning af små portrætter af de mange $\mathrm{i}$ den historiske akt deltagende personer, som var alle det daværende danske samf unds store navne.

Da krigen brad ud i foräret 1848 , meldte Schack sig igen til aktiv tjeneste. Han kom først til espingolbatteriet og derefter fra juli 1848 til 3. reservebataillon med udnavnelse til kaptajn. Større oplevelser, militare eller kunstneriske, synes det forste krigsår ikke at have budt på. Dog var Schack med i kampen om Haderslev 29. juni 1848. Formentlig hidrører "Episode fra $1848 \star^{4}$ fra dette âr tillige med et lithografi, følgeblad til "Heindal ", med titlen Holdt under marchen, skizze fra krigen*, som viser soldater under hvil ved et bondehus. Billedet er ikke signeret, men henføres af Jørgen Paulsen, som det synes med gode grunde, til Sophus Schack.

Ved felttogets begyndelse i 1849 gik den danske strategi ud pá, at en del af hæren skulle rykke syd på fra Kolding, en anden ved hjælp af flåden gøre landgang ved Egernførde, og endelig skulle hærens hovedstyrke angribe fra Als. Det ville således være muligt ved udnyttelse af den maritime overlegenhed at angribe fjenden fra tre sider.

Den 3. april gik de danske tropper over fra Als til Sundeved, hvor tyskerne måtte trække sig tilbage. I de folgende dage kom det til flere sammenstød, hvor først slesvigholstenerne under Bonin var i ilden, derefter kom turen til rigstropper fra Hannover, Würtemberg og Baden under general Wynecken. Den betydeligste af disse fægtninger var den ved Ullerup, som fandt sted den 6 . april. ${ }^{\circ}$ Ved denne lejlighed kom fire danske batailloner med otte 
kanoner til at stå overfor general Wyneckens otte batailloner med 24 kanoner. 3. reservebataillon under major Lorentzen ${ }^{7}$ stod om morgenen kl. 6 ved Sottrup kirke og afmarcherede herfra kl. 8 til Philipsborg, en gård midtvejs mellem Vester Sottrup og Ullerup, som har faet sit navn efter en af herlug Philip af Lyksborg i 1633 anlagt borg. Sydøst for gârden posteredes bataillonens 3 . og 4 . kompagni; Schack var chef for det førstnavnte. I forste omgang trængte hannoveranerne frem og besatte Ullerup, mens de danske tropper langsomt veg tilbage. Ved middagstid sendtes tre kompagnier frem til støtte for højre fløj, men trængtes af overmagten hen mod skoven vest for Casmus Mølle. To kanoner blev da sendt til undsætning. Det hjalp på humøret, og et modangreb kunne sættes ind; men dermed var også den meste ammunition bortskudt. Endelig satte general Bülow 3. reserve-jægerkorps, der var holdt tilbage som reserve, ind i fægtningen, og efter heftige kampe kunne de danske tropper henad klokken 6 atter rykke ind $i$ Ullerup. De kunne derefter omsider gå $i$ gang med den to gange afbrudte kogning af middagsmaden. ${ }^{8}$ I denne forbindelse fortæller Schack et pudsigt tilfælde om en af soldaterne, som nødigt sä, at provianten skulle falde $i$ fjendens vold, hvorfor han tog de netop udleverede $19^{1 / 2}$ pund kød med sig, en betydelig ekstra byrde, som han troligt bar under hele slaget.

I begyndelsen af kampen faldt en officer, hårdt sâret. To ambulancesoldater kom til. Den ene af dem blev straks ramt af en kugle. En officer og en underofficer greb da båren; men også officeren faldt straks. Schack var interesseret i mekaniske projekter og havde iøvrigt i $\mathbf{1 8 3 8}$ malet "En projektmager". Inspireret af denne dystre episode ${ }^{10}$ blev Schack selv projektmager og udtænkte idéen til en anbulance på hjul, som kun krævede én mands indsats. ${ }^{11}$ Opfindelsen blev realiseret, og skæbnen ville, at Schack selv kom til at indvie den, da han blev sâret den 7 . august $1850 .^{12}$ På Schacks maleri af Istedslaget ses en ambulance på hjul midt $i$ billedet. Det er formentlig hans egen opfindelse, han på denne måde har gengivet.

Dagen før slaget havde A. P. Madsen i sin skitsebog tegnet et motiv fra Ullerup med soldater under hvil. ${ }^{13}$ Dette lette blyantsrids er sammen med kunstnerens andre skitser fra krigstiden kommet til Koldinghus. ${ }^{14}$ På selve kampdagen, hvor han iøvrigt blev 
såret, havde Madsen utvivlsomt andet at gøre end at tegne, og det eneste hidtil kendte billede af Ullerupkampen skyldes F. C. Lund. ${ }^{15}$ Selve tegningen kendes nu ikke mere; men den er gengivet $\mathrm{i}$ kemitypi af Kittendroff \& Aagaard og anvendt som illustration i " Danmarks Kamp for Slesvig i Aarene 1848 og 49 «.

Schacks tegning, der dukkede op i Norge og nu findes på Koldinghus, viser en episode af kampen, der, som det ofte var tilfældet $i$ det østlige Sønderjylland, foregik som fægtning fra hegn til hegn. Danske soldater med fuld oppakning rykker netop frem fra et stensat dige med stynede træer. Nogle sảrede og faldne ligger i ly af diget, mens en menig soldat i forgrunden til højre har ladestokken nede i geværet, og en officer med bind om panden, det må være kaptajn Schack selv, med dragen sabel forcerer gærdet og gâr frem mod fjenden. Tegningen er udført med blyant, og dens mål er $23 \times 32 \mathrm{~cm}$. Den er signeret i nederste højre hjørne. Efter sin teknik med bløde blyantstoner og stedvis anvendelse af dækhvidt kan tegningen tænkes som forlæg for et lithografi. Hvis det har været hensigten, er den dog ikke blevet realiseret.

Det er bemærkelsesværdigt, at de danske soldater ses at kæmpe med fuld oppakning. Det indskærpedes overfor soldaterne, at næst efter ikke at spare sit krudt til man kunne se det hvide i sin fjendes øje, var det altid et håndgribeligt bevis på en slet soldat,' når han under kampen lettede sig for andet end krudt og kugler. En officer forlangte ligefrem, at den, der mistede noget under slaget, selv skulle komme til at hetale det. Insurgenterne foretrak derimod at kæmpe uden oppakning. ${ }^{16}$ Hverken på dette eller andre punkter kan der anmarkes noget mod 3. reserve-bataillon. Det hedder i major Lorentzens rapport, "at samtlige Officerer, Underofficerer og Mandskab til Fulde have opfyldt deres Pligt «. Tabslisten var heller ikke ubetydelig. Otte officerer, otte underofficerer og 87 menige meldes døde, sårede eller savnede. ${ }^{17}$ Kaptajn Schack blev kun let såret og er ikke medregnet i nævnte tal.

Nogen betydning for krigens forløb fik kampen om Ullerup trods den ydede indsats ikke. På grund af ændrede dispositioner rømmedes kort efter Sundeved og Dybbølbjerg med de fortrinlige stillinger og, som Læssøe hævdede, den for vore tropper gunstigste kampplads. ${ }^{18}$ Initiativet overlodes til fjenden.

Under 1849-felttoget blev Schack nærmere bekendt med general 





de Meza og var en tid lang denne lidet indladende officers nærmeste omgang. Den fint dannede de Meza havde udtalte kunstneriske interesser, og selv om musikken stod hans hjerte nærmest, var han heller ikke fremmed for selv at udøve tegnekunsten. I sin dagbog skrev de Meza under den 16. juli, at Schack ville "gjore den Ere at portrættere mig ${ }^{18}{ }^{1 \theta}$ Efter seancen kritiserede de Meza forskellige detailler samt "attituden", altså holdningen. Schack tog hensyn til indvendingerne, og den 9 . august kunne generalen betragte det ændrede portræt "med Velbehag " ${ }^{20}$ Portrættet, en vandfarvetegning ${ }^{21}$ er formentlig den, som kong Frederik VII siden erhvervede og havde hængende i sit kabinet.

Også andre end de Meza satte pris på Schacks selskab. Flere gange var han gæst hos oberst $J$. Th. Ræder, der havde deltaget $i$ Ullerup-kampen som bataillonschef. Bekendtskabet var iøvrigt af ældre dato, for omkring 1840 havde Schack malet Ræders portræt. Om et parti hos maleren, hvor Ræder og hans adjudant var indbudt, hedder det, at man morede sig godt ved at høre hans historier, der betegnes som uudtommelige.

Fra det tredie felttog fik Schack malet et lille maleri af en episode af Istedslaget, 3. brigades angreb på Solbro under oberst Schepelern. ${ }^{23}$ Derefter samlede han sig om den opgave med udnyttelse af de officersportrætter, han allerede havde tegnet, at fremstille en gruppe af arméens højere officerer. Schack var, som nævnt, atter blevet såret i kampen, og under rekonvalescensen havde han god tid til at gennemtænke arrangementet og gennemdrøfte det med de Meza. ${ }^{24}$ Oprindelig havde han tænkt sig at gengive krigsrådet i Bilskov, men opgav det til fordel for et friere arrangement. Det lykkedes ham at gennemfore planen. Den 26. december var han færdig med arbejdet, og det store lithografi, ${ }^{25}$ som udsendtes af E. Bærentzen \& Co. blev Schacks mest kendte bidrag til treårskrigens billedstof.

Schack havde gennemført sin dobbelte opgave under krigen: at være aktiv officer og samtidig at dyrke kunsten. Lidt laurbær var der også blevet ham til del. Den 9. september 1849 fik han ridderkorset. Men med al respekt for hans indsats i Ullerup-affæren var det dog ved angrebet på en skanse foran Frederikstad den 7. august 1850 , at han fortrinsvis udmærkede sig. Det var ved den lejlighed, at han igen blev såret. Schack tog gerne mod laur- 
bærrene. Lidt maliciøst fortælles det, ${ }^{28}$ at han meldte sig helbredet den dag, hans bataillon i januar 18.51 skulle overføres fra Flensborg til København. Indtogets hyldest var også værd at tage med.

Efter krigen delte Schack atter sin tid og indsats mellem militæret og kunsten, samtidig med at han fik tid til at skrive et par bøger af tildels kuriøs natur. I 1864 rykkede Sophus Schack igen i felten. Ved stormen på Dybbøl den 18. april blev han hårdt såret, og den 21. april døde han på et lazaret i København. ${ }^{27}$

De få krigsbilleder, vi kender fra Schacks hånd, gengiver en enkelt episode, således også det fra Ullerup, som åbenbart viser det tidspunkt, da det endelige modstød mod fjendens fremrykning sættes ind. Siørre bataillemalerier har ikke fristet kunstneren, som iøvrigt også helst holdt sig til beskedne formater. Han har ikke indladt sig på at konkurrere med Sonne og Simonsen, men foretrukket at gøre sin betydeligste indsats på eget område, det store gruppebillede. Trods perioder, hvor den militære tjeneste ikke var særlig tyngende, var det ikke mange af sine oplevelser i felten, Schack fik omsat $i$ billedform. Nogen let hând som hans meget produktive kolleger F. C. Lund og A. P. Madsen synes han ikke at have haft. Men måske har der eksisteret flere skitser, for $i$ hans hog »Bidrag til den danske Nations Karakteristik i Billeder fra Krigen 1848-50 « (Khvn. 1860) er optaget atten kemitypier, der ligesom teksten har sin største værd, hvor fremstillingen bygger på egne oplevelser og erindringer.

Hverken som slagmaler eller i kunstens andre provinser nåede Schack frem i første række; men han har med sit flittigt kultiverede talent præsteret det respektable. 


\section{NOTER:}

1. Jorgen Paulsen: Billeder fra Treårskrigen 1848-1849-1850. Udgivet af Det nationalhistoriske Museum på Frederiksborg 1952.

2. Johan Hansens samling 1486.

3. Leo Swane: Omkring Christian VIII's Salving; Kunstmuseets Årsskrift XXX, 47-58 (1943). Albert Thomsen: Nogle til Sophus Schacks billede; Danske Museer II, 59-66 (1951).

4. Johan Hansens samling 1487.

5. Jorgen Paulsen, anf. vark nr. 116.

6. Den dansk-tydske Krig $1848-50$ udg. af Generalstaben II, 1, 406--14. (Khvn. 1875).

7. Major Lorentzens rapport over 3. reserve-bataillons bevægelser 6 . april 1849, skrevet i kantonnement i Dybbol dagen efter, forefindes i Hærens Arkiv i Koloenhavn. Herfra har krigsmindesamlingerne pai Koldinghus venligst fact en fotografisk kopi overladt.

8. J. Th. Ræder: Krigserindringer fra 1848-50, 141. (Khvn. 1911).

9. Sophus Schack: Bidrag til den danske Nations Karakteristik i Billeder fra Krigen 1848-50, 19. (Khvn. 1860).

10. Formentlig den samme hændelse, der er omtalt i Breve fra danske Krigsmænd samlede af C. F. Allen, 94. (Khvn. 1873).

11. Schack: Bidrag, 52.

12. H. G. Grüner: Erindringer fra Felttoget 1850, 23. (Khvn. 1901).

13. Jorgen Paulsen nr. 157.

14. Koldinghus inv. $\mathrm{nr} .11157 \mathrm{~g}$.

15. Jørgen Paulsen nr. 158.

16. S. Schack: Bidrag, 19.

17. Nogle af de savnede menige må formentlig være dukket op igen, for den officielle tahsliste melder ikke 87, men 49 menige savnet, heraf 11 dode og én taget til fange. Af de deltagende troppeafdelinger havde 3 . reserve-bataillon de storste tab. Den totale tabsliste er publiceret som Bilag I til Generalstabens værk.

18. O. Vaupell: Læessies Levned, 117 (Khvn. 1895); P. Andræ: W. H. F. A. Lassøe, 128 (Khvn. 1912).

19. General de Mezas Krigs-Daghoger fra Arene 1849-1851 ved K. C. Rockstroh, 90. (Khvn. 1928).

20. Sst. 102.

21. Jorgen Paulsen nr. 502 a. de Mezas Krigsdagbøger, 229.

22. J. Th. Rader: Krigserindringer fra 1848-50, 208. (Khvn. 1911).

23. Jargen Paulsen nr. 305.

24. de Mezas Krigsdagbnger, 211, 218.

25. Jorgen Paulsen nr. 335.

26. H. G. Grüner: Erindringer fra Felttoget 1850, 11. (Khvn. 1901).

27. Axel F. Hansen: Mindeskrift over de i 1864 faldne Officerer, 184. (Khvn. 1909). 